\title{
MRI evaluation of myelopathic pain after spinal cord injury or spinal cord tumor surgery
}

\author{
Osahiko Tsuji ${ }^{1}$, Kohei Matsubayashi ${ }^{1,2}$, Yosuke Horiuchi ${ }^{1,3}$, Yuji Komaki ${ }^{4}$, \\ Junichi Hata ${ }^{4}$, Tsunehiko Konomi ${ }^{2}$, Kanehiro Fujiyoshi ${ }^{2}$, \\ Shizuko Kosugi ${ }^{5}$, and Masaya Nakamura ${ }^{1}$ \\ ${ }^{1}$ Department of Orthopaedic Surgery, Keio University School of Medicine \\ ${ }^{2}$ Department of Orthopaedic Surgery, Murayama Medical Center \\ ${ }^{3}$ Department of Orthopaedic Surgery, JCHO Saitama Medical Center \\ ${ }^{4}$ Department of Physiology, Keio University School of Medicine \\ ${ }^{5}$ Department of Anesthesiology, Keio University School of Medicine
}

\begin{abstract}
Patients with spinal cord injury suffered from not only motor paralysis but also intolerable neuropathic pain. Regarding the mechanism, various theories such as functional changes in the brain, disorders within the spinal dorsal horn and/or spinothalamic tract have been proposed. However, the feasible animal models with solid reproducibility has been insufficiently verified. We have established the mice fMRI system, reported the results of mice-fMRI after L5 nerve injury and resting state-fMRI imaging after thoracic cord transection injury in mice. Furthermore, in a clinical setting we evaluated the brain morphometry of the cases with spinal intramedullary tumor surgery by VBM, and found the gray matter volume of some brain regions was increased related with pain intensity. Besides fMRI and VBM analysis, we developed diffusion MRI techniques which could depict neuronal axons and myelination within the spinal cord ("diffusion tensor tractgraphy" and "myelin map", respectively). In this review, I would like to outline our results of MRI analysis of neuropathic pain so far.
\end{abstract}

Keywords

MRI; fMRI; Myelin map; Neuropathic/myelopathic pain

\footnotetext{
MRI による脊髄損傷後/脊髄腫瘍術後疼痛評価の試み

辻収彦 $1 /$ 松林 紘平 1,2 /堀内 陽介 1,3 /小牧 裕司 $4 /$ 畑 純一 4

許斐 恒彦 $2 /$ 藤吉 兼浩 $2 /$ 小杉 志都子 5 / 中村 雅也 ${ }^{1}$

1 慶應義塾大学医学部 整形外科学教室, 2 村山医療センター 整形外科,

$3 \mathrm{JCHO}$ 埼玉メディカルセンター 整形外科, 4 慶應義塾大学医学部 生理学教室,

5 慶應義塾大学医学部 麻醉学教室
} 


\section{はじめに}

脊髄損傷は中枢神経である脊髄を損傷するこ とで，四肢・体幹・膀胱の完全または不全麻痺 を引き起こす病態である。本邦における新規脊 損患者数は毎年約 5,000 例, 慢性期を含めると 総患者数は 10～ 20 万例以上と推定されている 1$)$ 現在の医学では損傷した脊髄を復元することは 不可能であり，治療法は脱臼・骨折を伴う場合 には脊椎を安定化させる固定術，脊䯣圧排を伴 う場合には除圧術を行い, 残存した機能を最大 限に活用するためのリハビリテーションを行う ことが最善手となるのが現実である 2,3$)$ 。脊髄損 傷によって生じる運動麻痺による患者の社会 的・経済的に莫大な損失が生じることは自明で あるが，運動麻痺に加えて脊髄損傷後疼痛もま た大きな問題となる ${ }^{4)}$ 。春髄損傷後患者の約 $65 \%$ は何らかの痛みを自覚するとされ，その約 $1 / 3$, 即ち $20 \%$ 強は耐えがたい痛みと感じてい ることが知られている5)。

われわれはこれまでに，脊髄損傷後の運動麻 痺の克服に主眼を置き神経幹細胞，更にはiPS 細胞由来神経幹/前駆細胞移植の有効性および 安全性についての科学的エビデンスをげっ歯類 更には霊長類 (サル) 脊髄損傷モデルを用いて 積み重ね，2019年 2 月 18 日に特定認定再生医 療等委員会および厚生科学審議会で第 1 種再生 医療提供計画（臨床計画）が認められ，ヒト iPS 細胞由来神経前駆細胞を用いた亜急性期脊䯣損 傷（澒髄および胸髄の完全損傷）への再生医療 の Phase I/IIa 試験の “First-human-trial” の準 備を進めている 6)。しかし前述のように実臨床 においては，運動麻㽻のみならず脊髄損傷後の 強い疼痛に苛まれている患者さんは多数おり， 具体的には脊髄損傷後の Below pain を有する 患者さんでより疼痛の程度は有意に強く，また
AIS 分類 B (運動完全麻痺, 感覚不全麻痺) の症 例ではより疼痛が強いことが判明しており7), 運動麻痺に加えて痛みの克服もわれわれに課せ られた大きな課題である。

本稿においては，これまでわれわれが取り組 んできたマウス神経障害性モデルにおける脳 functional MRI (以下 MRI)，マウス胸髄切断モ デルにおける覚醒下 fMRI (resting state f-MRI: 以下 rs-fMRI)，更には脊髄䯣内腫瘍術後疼痛症 例における脳 MRI の Voxel-based morphometry （以下 VBM）による評価について概説し，更に はわれわれが開発した，マウス/ヒトにおいて MRI にて髄鞘 Myelin を in vivo で可視化可能に した“Myelin map”についても解説したい。

\section{マウス神経障害性疼痛モデルにおける 脳 fMRI}

fMRI は MRI のもたらす構造情報の上に，脳 の機能活動がどの部位で起こっているかを画像 化するものである。即ち，何らかの刺激に対す る脳血流量の変化を検出して BOLD (Blood Oxygenation Level Dependent）信号として表出 し，脳の活動領域を画像化する手法である ${ }^{8)}$ 。 fMRI は脳活動と相関するといわれており，脳 の機能活動としてシナプス活性が増加すると, 近接するアストロサイトやニューロンが感知し て血液量, 血流量, 血中酸素濃度の変化が起こ ることで oxy/deoxy-Hb の磁化率に差異が生じ, それを BOLD 信号として捉えている。マウス 脳における fMRI 撮像は 2001 年に $11.7 \mathrm{~T}$ の高 磁場 MRI を用いて初めて成功し報告された 9 。 fMRI 研究においてマウスを用いる短所として は，1）サイズが非常に小さく，ヒト大脳と比し てマウス大脳容積は約 4000 5000 分の 1 とさ れること，2）下等な動物のため認知機能的に劣 


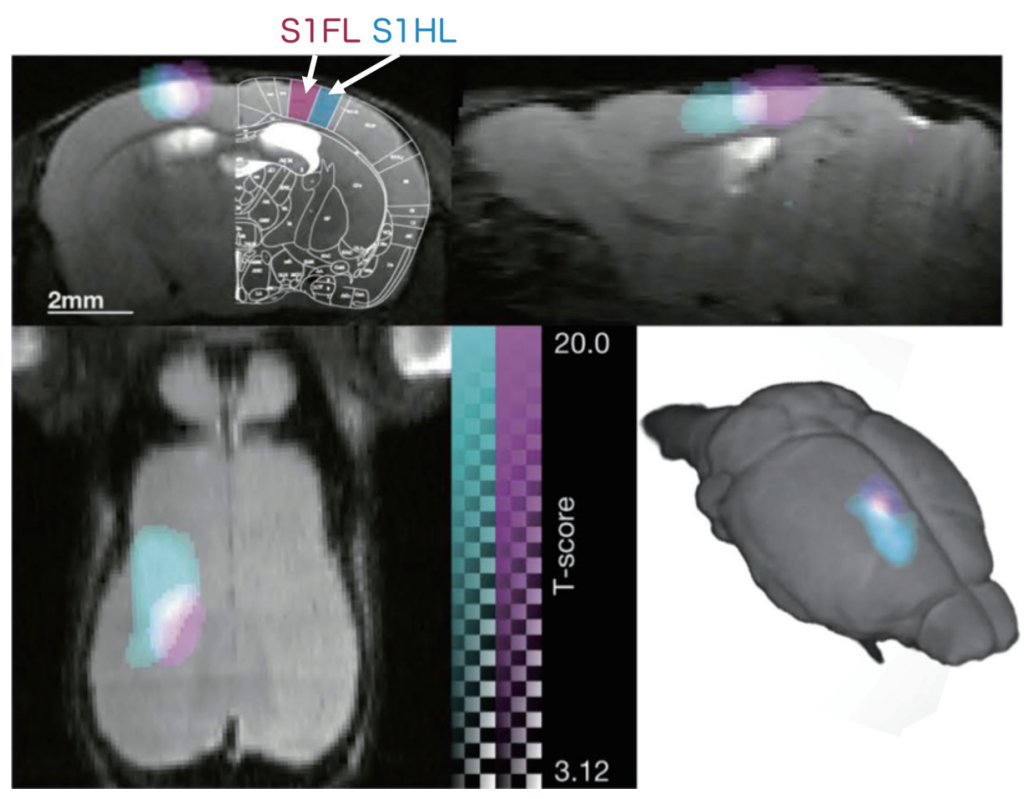

Fig.1 前肢 / 後肢刺激による正常マ ウス $\mathrm{fMRI}$

野生型マウスの左前肢および左後肢 をそれぞれフィラメントで刺激し， 前肢 (紫色) と後肢（水色）それぞれ の BOLD 反応を対側一次体性感覚野 S1 において描き分けることに成功し た。(文献 11 より引用・改変) (Brain map は The mouse brain in stereotaxic coordinates 3rd edition より引用・参 照）

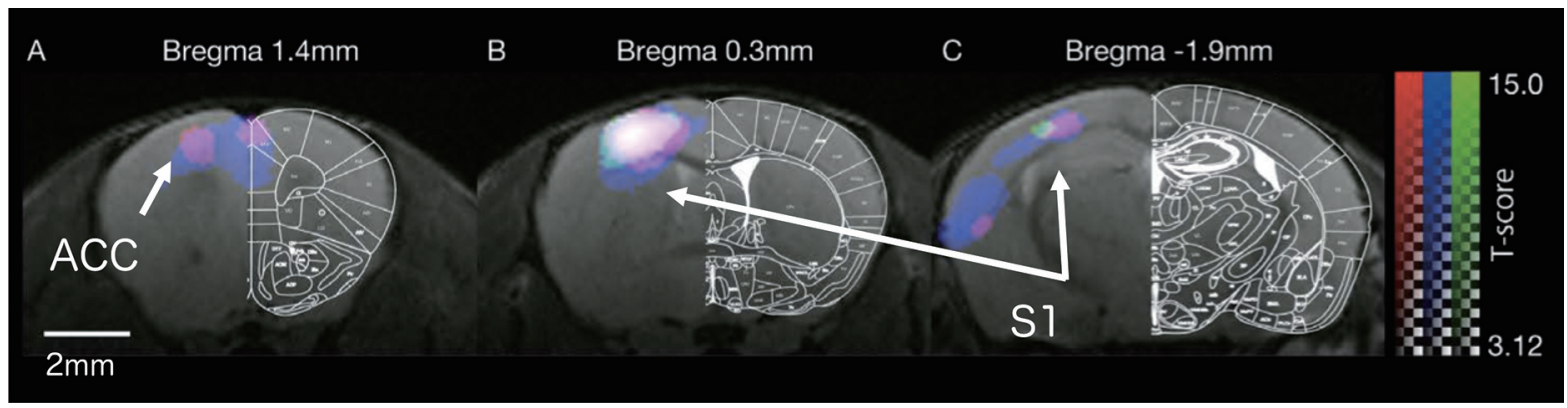

C線維, $A \delta$ 線維, $A B$ 線維 $[p<0.001]$

Fig.2 神経線維選択的な刺激による正常マウス fMRI

Neurometer による神経線維選択的な刺激により，各線維刺激に応じた反応部位を検出することに成功した。ACC：前 帯状回, S1 : 一次体性感覚野 (文献 11 より引用・改变)

ること，3）麻酔薬による鎮静の fMRI への影響 があり撮像が難しいこと，などが指摘されてき た。しかし遺伝子改変技術に代表される豊富な 疾患モデルがあり, 遺伝的背景が均一化されて いること, 治療技術・創薬開発の客観的評価の 基礎となること, 解剖生理学的解析との関連付 けが可能であること，という非常に多くの長所 も，小さい個体ではあるにもかかわらず有して いる。そこでわれわれは 7T 動物用高磁場 MRI に, Cryoprobe ${ }^{10)}$ と呼ばれる MRI 磁場を増強
する作用を有する機器を併用し，マウスを生か したままin vivoでの脳 $\mathrm{PMRI}$ 撮像に成功し報 告した 11)。まず全身麻酔下に鎮静された，神経 損傷の加わっていない野生型マウスに, 左前 肢・左後肢のそれぞれを von Frey フィラメント で刺激すると，各刺激ごとに起こる BOLD 反 応部位が同じ一次体性感覚野 S1 の中で前肢/後 肢それぞれに描き分けられ，その反応部位は Brain map で提唱されているものと一致してい た (Fig.1)11)。更にわれわれは, Neurometer ${ }^{\mathrm{R}}$ 
Myelopathic pain evaluation by MRI

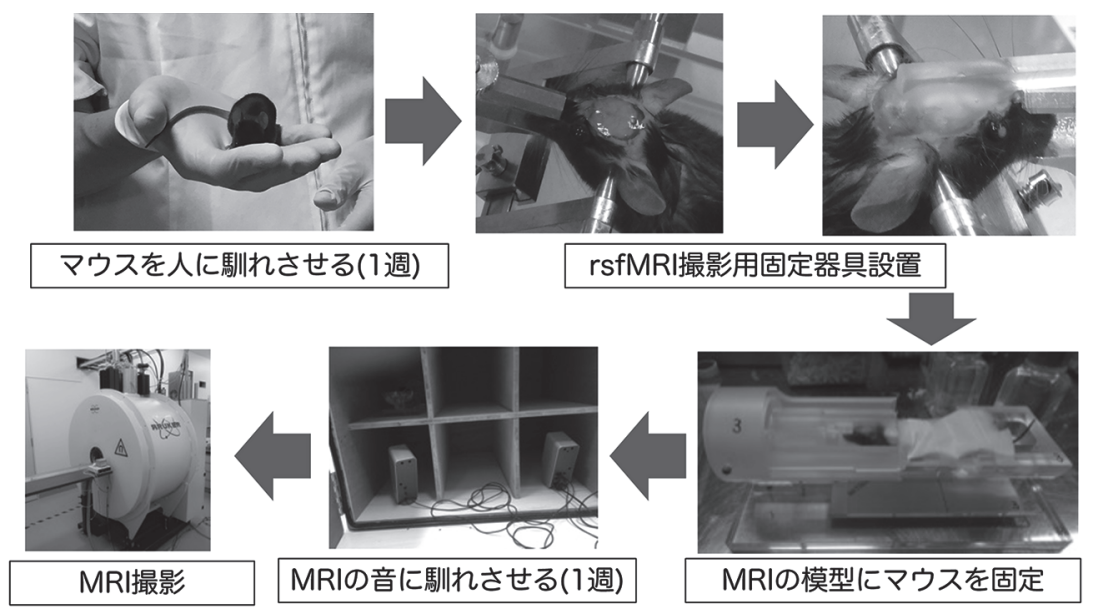

Fig.3 rs-fMRI 撮影までの流れ 覚醒下で安定した撮像結果を得る ために，まずヒトの手に乗せてマ ウスを馴化し (1 週), その後全身 麻酔下に MRI 撮影用固定器具を頭 蓋骨に設置した後, 覚醒下にMRI 撮像機器と同じ環境（模型内に固 定しスピーカーで MRI 撮像音を聞 かせる）に一定時間置き馴化させ ることを更に 1 週行った後に, 実 際の rs-fMRI 撮像となる。（慶應義 塾大学精神科田中謙二先生の研究 室より技術指導頂いた）

(Neurotron Inc., Baltimore, MD) を用いること で，末梢神経線維選択的な刺激 ( $\mathrm{A} \beta$ 線維 : 触知 覚· $2000 \mathrm{~Hz}, \mathrm{~A} \delta$ 線維: 鋭い痛覚・ $250 \mathrm{~Hz}, \mathrm{C}$ 線維: 鈍い痛覚・5 Hz) を加え, 同様に fMRI 撮 像を行った。その結果, $\mathrm{A} \beta$ 線維刺激では対側 の $\mathrm{S} 1$ に, $\mathrm{A} \beta$ 線維刺激では対側の $\mathrm{S} 1$ に加え前 帯状回 $(\mathrm{ACC})$ ・視床に, $\mathrm{C}$ 線維刺激では対側の $\mathrm{S} 1 ・ \mathrm{ACC}$ に BOLD 反応が，各線維刺激ごとに 異なる部位に検出され (Fig.2), 小さなマウス脳 においても選択的神経線維刺激による $\mathrm{fMRI} の$ 描出分けが可能であることを報告した。これら の結果に基づき，更にわれわれは神経障害性疼 痛モデル (modified Chung：L5 神経根切断モデ ル 12)）マウスを作成し，Neurometer を用いて 定常状態だと痛覚刺激と認識されない $\mathrm{A} \beta$ 神経 選択的刺激を患側後肢に行った。その結果，損 傷前には $\mathrm{A} \beta$ 刺激で検出されなかった ACCで の BOLD 反応が検出され, 即ち神経障害性モ デルマウス脳においてアロディニアを検出して いるものと考えられた ${ }^{11)}$

\section{マウス神経障害性疼痛モデル・胸䯣離断 モデル脳における rs-fMRI}

われわれはマウスにおける fMRI 撮像に成功
したが, 鎮静下 fMRI の limitation として, 麻 酔薬による脳血流への影響が挙げられる。近年, 覚醒下において, 皮膚刺激等の夕スクを何も与 えない状態での, 定常状態での脳の自発的な脳 活動を評価する rs-fMRI が注目され，既にヒト における撮像が進んでいる 13,14)。安静時での自 発的な脳活動由来の機能的な結合に関する情報 が rs-fMRI に含有されており，rs-fMRIにより 脳の各領域間の関係を検討することができるよ うになった。しかし前段と同様の理由で，小動 物であるマウスでの rs-fMRI を撮像する系は確 立されていなかった。そこでわれわれは，マウ スのヒトへの馴化，MRI 環境への馴化，撮像用 の独自の固定具の工夫等を行い (Fig.3)，神経障 害性疼痛モデルマウスでの rs-fMRI 撮像を行っ た。マウス脳 576 部位での機能連絡を正常マウ ス脳と比較解析した結果, 神経障害性疼痛モデ ルマウス脳において一次体性感覚野 S1 の機能 連絡低下，および ACC/視床後外側腹側核での 媒介中心性 (betweenness centrality) 増加が認め られた (Fig.4) 11)。更には，脊髄切断により後肢 完全麻痺となる脊髄損傷 (胸髄離断) モデルマ ウスを作成し，同様に rs-fMRI をin vivoにて 経時的に評価したところ，損傷前から損傷後 14 週（慢性期）にかけて，脳全体での機能連絡総 
a.

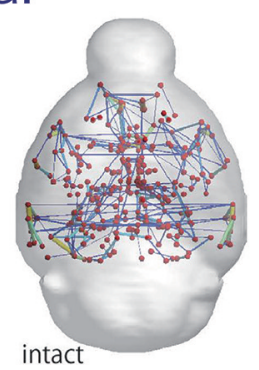

b.
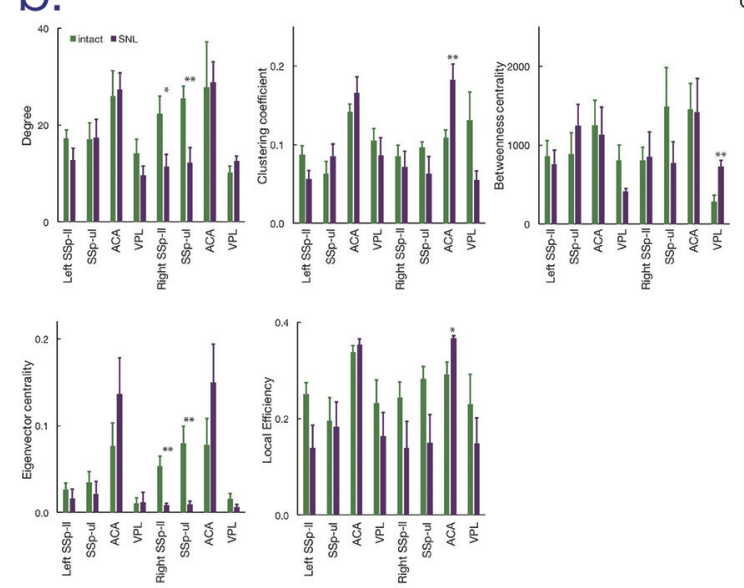
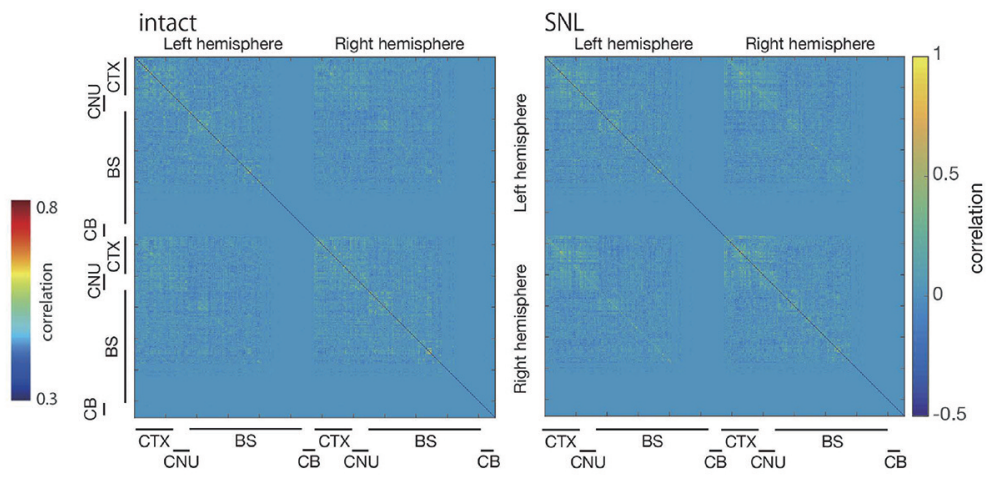

Fig.4 神経障害性疼痛モデルにおける rs-fMRI

a. マウス脳 576 箇所の機能連絡を解析

b. 神経障害性疼痛モデル (modified Chung モデル) マウス脳 において，体性感覚野S1 の機能連絡低下，ACA/VPL で の betweenness centrality 増加を認めた。(文献 11 より引 用・改変) a.

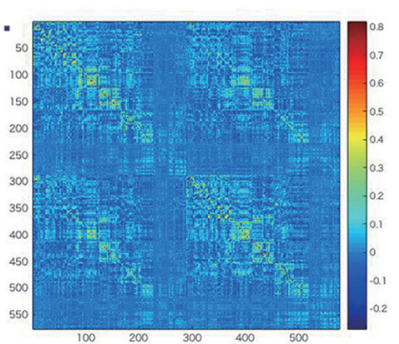

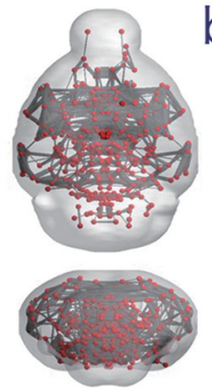

b.

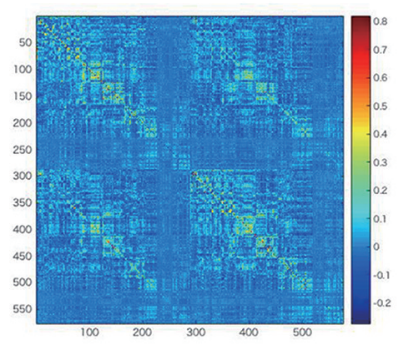

The strength of the whole brain

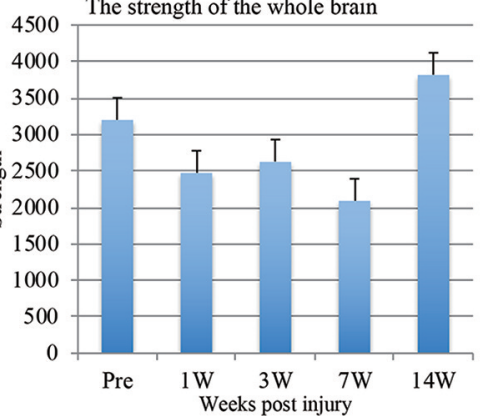

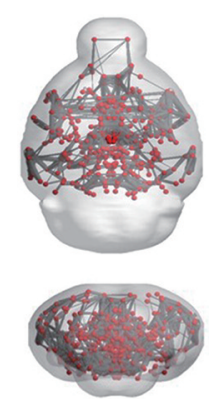

C.

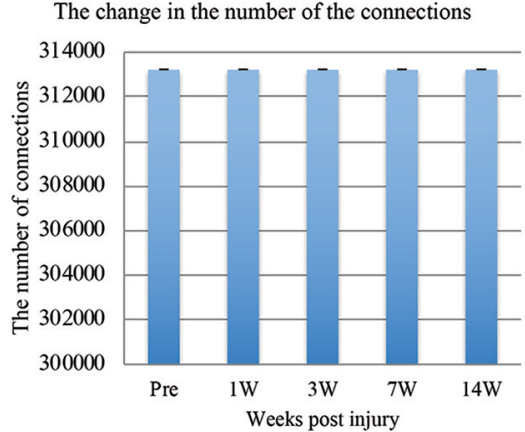

Fig.5 胸髄離断モデルマウスの rs-fRMI における脳機能連絡評価

マウスの脳の領域を 576 領域に区域分けし，領域同士の機能連絡について分類，視覚化した。 $\mathrm{a}$ : 損傷前マウスの脳機能連絡, $\mathrm{b}$ : 損傷後 14 週マウスの脳機能連絡, $\mathrm{c}$ : 脳全体の機能連絡の変化 脊髄損傷後の脳の機能連絡の総数は不変であったが強度が变化していた。(文献 15 より引用・改変) 


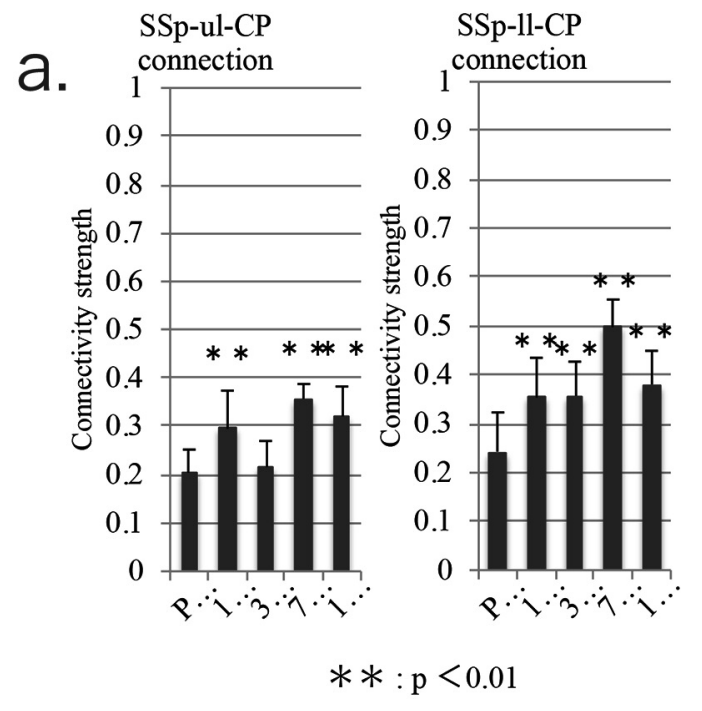

C.

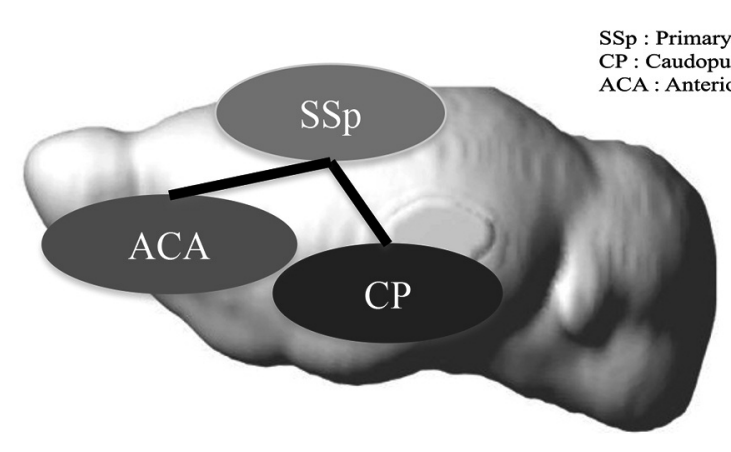

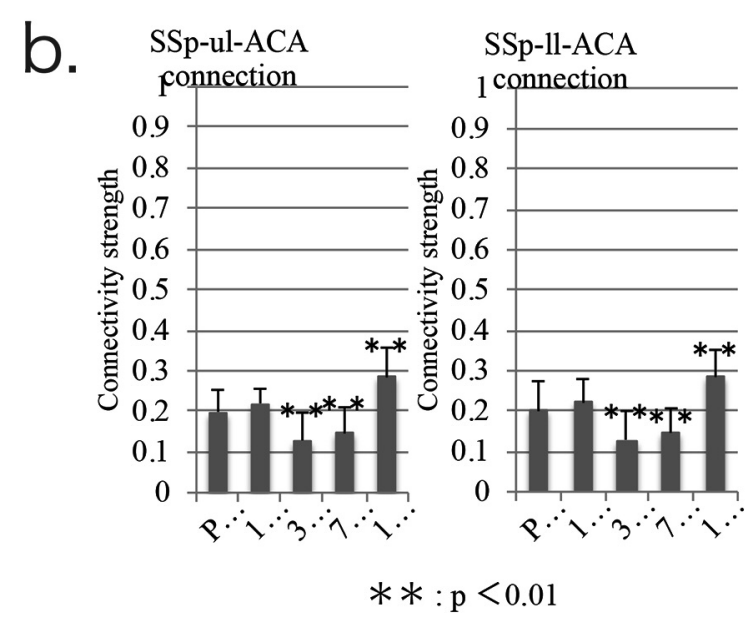

Fig.6 胸髄離断モデルマウス脳での一 次感覚野と尾状核被殼/前帯状皮質間 の機能連絡強度の変化

a. 一次感覚野 $(\mathrm{SSp})$ と尾状核被款 $(\mathrm{CP})$ と の間の機能連絡変化

b. 一次感覚野 (SSp) と前帯状皮質 (ACA) との間の機能連絡変化

いずれも脊䯣損傷後 14 週にかけて連絡 強度は有意に増加していた。CP/ACA は疼痛関連領域であり, 春䯣損傷後の 神経障害性疼痛を反映しているものと 考元られた。

c. 各領域間の連絡を表したシェーマ

(文献 15 ょり引用・改変)
数は不変であったが機能連絡強度は有意に変化 していた (Fig.5) 15)。有意な機能連絡の変化がみ られた一次運動野 (MOp) と一次感覚野 (SSp), 眼窩前頭皮質 (ORB), 前帯状皮質 (ACA) それ ぞれとの間の機能連絡強度について経時的に解 析したところ, MOp と前肢 SSp との機能連絡 強度は一過性に上昇後慢性期には有意に低下, $\mathrm{MOp}$ と後肢 SSp 間の連絡強度は慢性期に有意 に低下していた。一方で motivation area とされ る $\mathrm{ORB} / \mathrm{ACA}$ との間の連絡強度は損傷後経時 的に有意に上昇していた。即ち脊䯣損傷後の感 覚一運動機能の機能連絡強度低下は, 麻痺した 後肢を動かそうとする意欲を代償性に促進して
いる, と推察された。更には, SSp と疼痛関連 領域とされる尾状核被殼尾側被蓋部 $(\mathrm{CP})$ およ びACA との間の機能連絡強度を解析したとこ ろ, SSp と疼痛関連領域間の機能連絡は慢性期 に有意に強化されていた。このことは rs-fMRI により脊髄損傷後神経障害性疼痛の存在を示し ていると考えられた (Fig.6)。以上の結果はマウ スモデルでの評価であるが，今後ヒトにおいて も同様の結果が得られれば rs-fMRI が脊髄損傷 後の神経障害性疼痛を示すバイオマーカーとし て活用できる可能性があると言える ${ }^{15)}$ 。現在わ れわれは慢性期脊髄損傷患者さんにご協力頂き, ロボットスーツによるリハビリ介入前後での 
rs-fMRI を撮像し詳細な解析を行っているとこ ろである。

\section{脊髄髄内腫瘍術後疼痛の} VBM における評価

当施設ではこれまでに 2,000 例以上の脊髄腫 瘍の手術経験を有しており，難易度の高い髄内 腫瘍手術も数百例の症例数を数える。髄内腫瘍 術後は運動麻痺などの脱落症状リスクに加え， しびれを伴った強い疼痛により患者の日常生活 動作が著しく障害される場合があり，髄内腫瘍 摘出の際の myelotomyによる脊髄障害性疼痛 myelopathic pain と捉えている。われわれが 行った患者自記式アンケートによる結果では, 頝髄髄内腫瘍 29 例の解析では, 術後疼痛と運 動麻痺の強さに相関はみられないが, 術後麻疩 が高度にもかかわらず疼痛が軽微な例や，逆に 運動麻痺が軽微にもかかわらず疼痛が強い例と が存在し，後者は全例が At level 疼痛で脊髄後 角部に局在する血管系腫瘍であった 16)。一方， 胸髄髄内腫瘍術後 19 例の解析では, 術後の疼 痛と運動麻痺に弱い相関がみられ，その多くが Below pain であり，外側脊髄視床路と皮質脊䯣 路の障害の程度が同程度であったと推察された。 しかし脊䯣離断を行い完全麻痺となった 3 例で は術後疼痛の程度に大きなばらつきがあり，必 ずしも脊髄の投射路の障害のみでは説明がつか ず，脊髄髄内腫瘍術後疼痛のメカニズムには 未だ不明な点が多いと考えていた ${ }^{16) 。 そ こ て ゙ ~}$ 当院で脊髄髄内腫瘍手術を行った 49 例の方々 にご協力頂き，頭部 MRI によるVoxel-based morphometry (VBM) 評価を行い, 脊䯣障害性 疼痛と脳形態評価を詳細に行った。VBM とは, 特定の領域ではなく全脳を対象に，灰白質・白 質の密度や容積をボクセル毎に評価できる手法

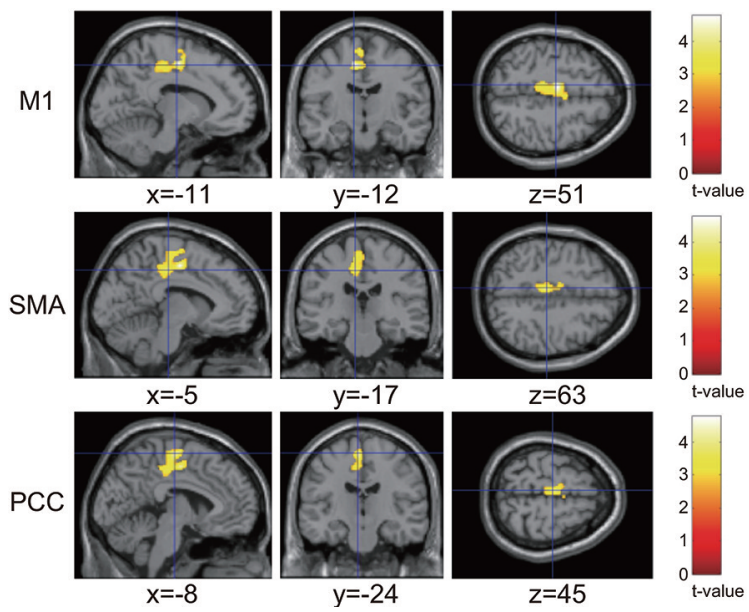

Fig.7 春髄髄内腫瘍術後疼痛患者における VBM 評 価

術後 $\mathrm{NRS} \geqq 3$ の疼痛を有する群では有意に左 M1 (一次運 動野), 左 SMA (補足運動野), 左 PCC (後帯状皮質) の 灰白質容積が増大していた。(文献 18 より引用・改変)

であり，20世紀末までの従来法は測定者が MRI 画像スライス一枚ごとに，解剖学的構造物 を基準として厳密に定義し，関心領域の境界を 手書きで書き込んでいく方法（ROI〔Region of interest] 法) であり，部位によっては数 10 スラ イスにわたる作業をやり遂げて，初めて体積が 測定可能となっていた。しかし ROI 法は測定 の検者間誤差が大きく，サンプルサイズも特定 部位に限定されるという久点を有していた。そ れに対し VBM は各個人の MRI 画像データを 標準脳座標上に変換し空間正規化をすることで, 自動的に全脳の形態学的解析を行うことができ る方法である 17)。われわれは脊髄䯣内腫瘍術後 49 例の症例のうち, $\mathrm{NRS} \geqq 3$ の疼痛 (At level, below level，または両方）を有する群と， $\mathrm{NRS}<3$ の疼痛が殆ど無い群との 2 群に分け $\mathrm{VBM}$ 解析を行ったところ, 疼痛群において左 一次運動野 (primary motor cortex : ブロードマ ン 4 野), 左補足運動野 (supplementary motor area：ブロードマン 6 野)，左後帯状皮質 
a.

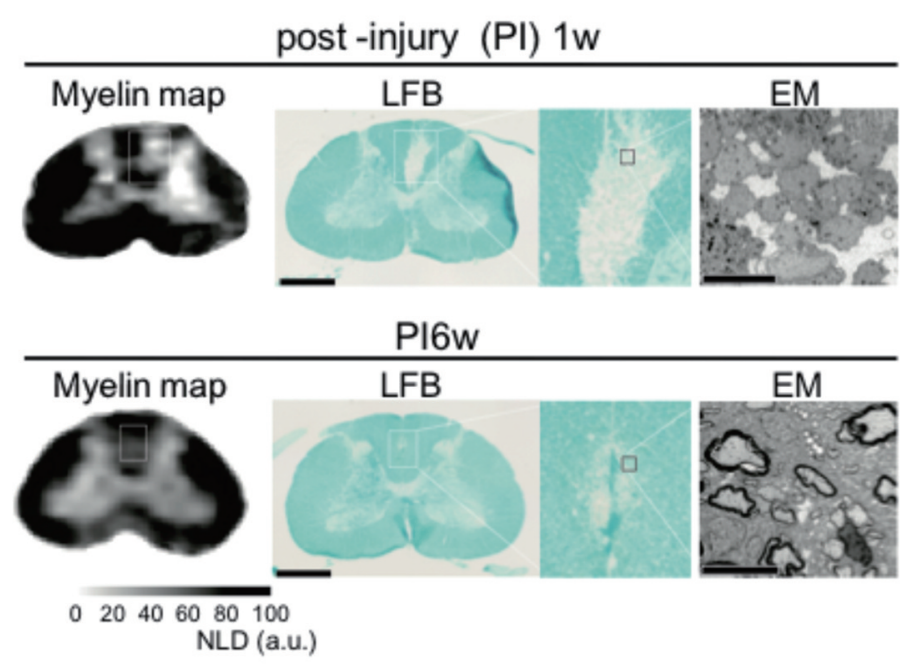

b.

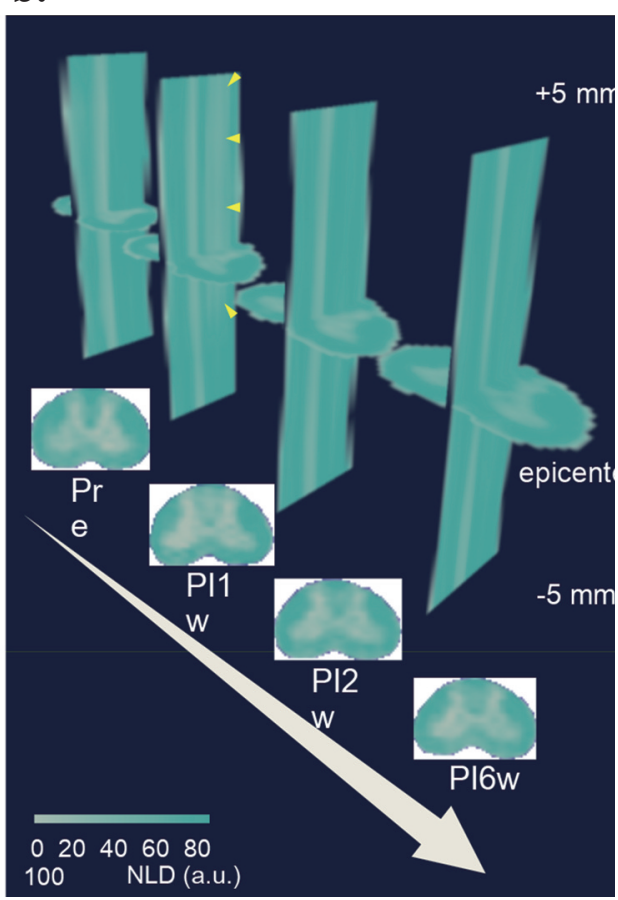

Fig.8 Myelin map : MRI で髄鞘を可視化

a. サル (コモンマーモセット) 脊髄への化学損傷脱髄モデル。脊髄後索にリゾホスファチジルコリン (LPC) を投与し一 過性に脱髄が生じ, 約 6 週後に再髄鞘化する。LFB は髄鞘染色を行った組織切片, Myelin map は同部位の MRI 画像 である。

$\mathrm{EM}$ : 電子顕微鏡像, LPC 投与後 1 週時点においては軸索周囲のミエリンが消失しているが， 6 週後には再髄鞘化し ている。

b. 同一化学損傷サル個体における Myelin map の経時的変化。(文献 15 より引用・改変)

(posterior cingulate cortex : ブロードマン 23 野) の灰白性容積が有意に増大していた ${ }^{18 ）}$ (Fig.7)。 また，NRS 值の大きさと灰白質容積の相関解析 を行ったところ，NRS 值が強くなるほど，左一 次運動野, 左後帯状皮質, および右上頭頂小葉 (superior parietal lobule : ブロードマン 5 野) の 灰白質容積が増大しており，また強い below painの存在がこれらの灰白質の増大と有意に関

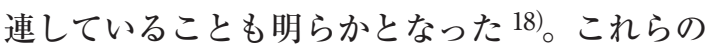
領域の灰白質増大が, 春䯣障害性疼痛の存在を 示唆する新たなバイオマーカーとなり得ると考 え, 今後更にサンプル数を増やして解析する必 要があると考えている。

\section{拡散 MRI によるによる軸索・喊鞘評価と 慢性疼痛}

神経障害性疼痛の原因として, 外傷や炎症, 腫瘍による何らかの神経損傷・障害の結果とし て, 髄鞘は脱髄し, 軸索にも強度の損傷が及ん だ場合には Waller 変性を生じることが提唱さ れている。われわれは上述の rs-fMRI, VBM 加えて, 拡散 MRIによる軸索損傷および脱髄 の評価も行ってきた。水分子の拡散異方性の最 大方向を追跡し画像化した MRI 像を拡散テン ソルトラクトグラフィー (diffusion tensor tractgraphy: DTT) と呼び, DTT によるマウ 

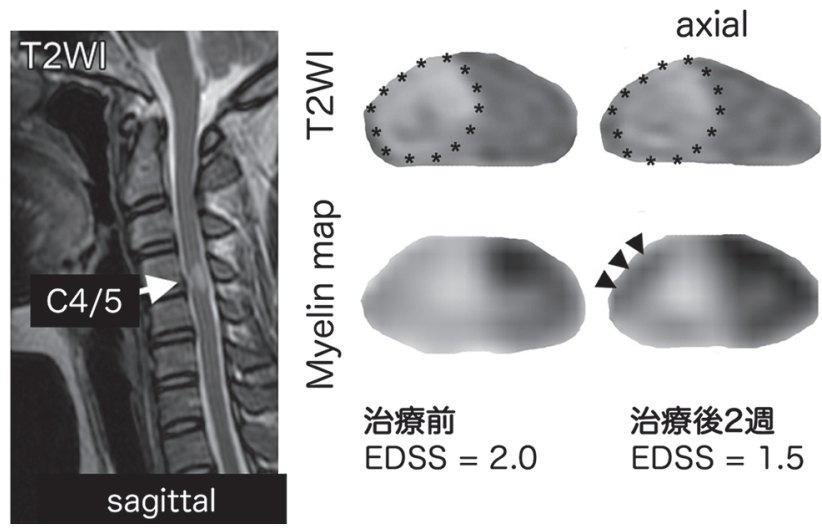

治療後 2 週

$\mathrm{EDSS}=1.5$
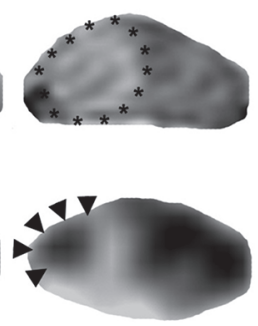

治療後10週 $\mathrm{EDSS}=0$
Fig.9 多発性硬化症脊䯣におけ る経時的な再䯣鞘化像

35 歳女性, 再発寛解型の MS。病 期 $: 1$ 年, EDSS $: 2.0$ 。ステロイ ドパルス療法により EDSSによる 機能回が得られ，同時に Myelin map による再髅鞘化を捉えること に成功した。

(文献 23 より引用・改変)
ス・サル脊髄損傷後の軸索の描出・定量評価を, 組織学的検証と共に行いその有用性を報告して きた 19,20,21)。サル損傷䅡䯙内において投射路選 択的に, 損傷後の Waller 変性を in vivo で経時 的に描出し，更に実臨床に打いて䅡椎症性脊揈 症の手術症例を対象に, 術後改善率と術前 DTT 評価とを定量的に解析し, 術前 DTT の fiber tract 比 (FT ratio : 最狭窄部の fiber 数/C2 高位の fiber 数) が $60 \%$ を下回ると術後改善率

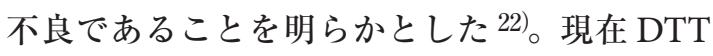
による頚椎後縦勒带骨化症の術後予後因子探索 を多施設研究で進めており, 術後の運動機能に 加えて術後疼痛・感覚障害との関連についても 知見が得られるか慎重に解析を進めている。

DTT は主に軸索を評価しているが, 疼痛・し びれと密接に関連すると言われている脱髄を可 視化することにもわれわれは成功している。 Q-space imaging という MRI 撮像法を応用し, 春鹃道内での䯣鞘を特異的に可視化できる “Myelin map”23)を用いることで, in vivoにおい て脳/脊髄内の䯣鞘を経時的に可視化・評価で き(Fig.8)，既に共同研究を行っている慶應義塾 大学神経内科 (中原仁教授)に扔いて脱髄性疾 患 (例 : 多発性硬化症) の臨床評価に応用してい る(Fig.9)。われわれは Myelin map 開発の中で, 一過性の脊髄化学損傷（脱髄）モデルとしてリ
ゾホスファチジルコリン (LPC) 投与をサル脊髄 後索に行ったが (Fig.8)，この LPC は細胞外に おいては autotaxin によって分解されリゾホス ファチジン酸 (LPA) となり, LPA が脱髄誘導 に働くとされる 24)。近年この LPA が慢性疼痛 患者の髄液中で疼痛強度に応じて増加している ことが報告され，LPA が後根神経節や脊髄後角 に打いて疼痛発症メカニズムに重要な役割を果 たしていると推察されている25)。今後，われわ れが開発して “Myelin map”を応用して, 脱䯣 と慢性疼痛・しびれとの詳細な解析を行いたい と考えている。

\section{おわりに}

本稿において，われわれがこれまでに行って きた，MRIを用いた疼痛評価研究（動物実験・ 臨床研究）について概説した。現在 DTT・ Myelin map の撮像は $3 \mathrm{~T}$ の MRI 臨床機を用い て, 通常の撮像に加えて約 5 分間追加の撮像時 間で可能となっている。しかし実際には，脊髄 での撮像となると絲と比してそのサイズの小さ さから精細な像を得ることが難しいという克服 すべき点も有る。脱髄を引き起こす LPA と疼 痛との関連が注目されてが抢り, 慢性疼痛さら にはしびれと脱髄との関連について更なる科学 
的知見を積み上げられるよう引き続き研究を 行っていきたいと考えている。

\section{文 献}

1) Katoh, S., Shingu, H., Ikata, T., Iwatsubo, E., Sports-related spinal cord injury in Japan (from the nationwide spinal cord injury registry between 1990 and 1992), Spinal Cord, 34 (1996) 416-421.

2) Taghva, A., Hoh, D.J., Lauryssen, C.L., Advances in the management of spinal cord and spinal column injuries, Handb. Clin. Neurol., 109 (2012) 105-130.

3) Ditunno, J.F., Cardenas, D.D., Formal, C., Dalal, K., Advances in the rehabilitation management of acute spinal cord injury, Handb. Clin. Neurol., 109 (2012) 181-195.

4) Bryce, T.N., Biering-Sorensen, F., Finnerup, N.B., Cardenas, D.D., Defrin, R., Lundeberg, T., Norrbrink, C., Richards, J.S., Siddall, P., Stripling, T., Treede, R.D., Waxman, S.G., WiderströmNoga, E., Yezierski, R.P., Dijkers, M., International spinal cord injury pain classification: part I. Background and description. March 6-7, 2009, Spinal Cord, 50 (2012) 413-417.

5) Siddall, P.J., Loeser, J.D., Pain following spinal cord injury, Spinal Cord, 39 (2001) 63-73.

6) Tsuji, O., Sugai, K., Yamaguchi, R., Tashiro, S., Nagoshi, N., Kohyama, J., Iida, T., Ohkubo, T., Itakura, G., Isoda, M., Shinozaki, M., Fujiyoshi, K., Kanemura, Y., Yamanaka, S., Nakamura, M., Okano, H., Concise Review: Laying the Groundwork for a First-In-Human Study of an Induced Pluripotent Stem Cell-Based Intervention for Spinal Cord Injury, Stem Cells, 37 (2019) 6-13.

7) Nagoshi, N., Kaneko, S., Fujiyoshi, K., Takemitsu, M., Yagi, M., Iizuka, S., Miyake, A., Hasegawa, A., Machida, M., Konomi, T., Machida, M., Asazuma, T., Nakamura, M., Characteristics of neuropathic pain and its relationship with quality of life in 72 patients with spinal cord injury, Spinal Cord, 54 (2016) 656-661.

8) Ogawa, S., Lee, T.M., Stepnoski, R., Chen, W., Zhu, X.H., Ugurbil, K., An approach to probe some neural systems interaction by functional MRI at neural time scale down to milliseconds, Proc. Natl. Acad. Sci. USA, 97 (2000) 1102611031.

9) Ahrens, E.T., Dubowitz, D.J., Peripheral somatosensory fMRI in mouse at $11.7 \mathrm{~T}, \mathrm{NMR}$ Biomed., 14 (2001) 318-324.
10) Baltes, C., Radzwill, N., Bosshard, S., Marek, D., Rudin, M., Micro MRI of the mouse brain using a novel $400 \mathrm{MHz}$ cryogenic quadrature $\mathrm{RF}$ probe, NMR Biomed., 22 (2009) 834-842.

11) Komaki, Y., Hikishima, K., Shibata, S., Konomi, T., Seki, F., Yamada, M., Miyasaka, N., Fujiyoshi, K., Okano, H.J., Nakamura, M., Okano, H., Functional brain mapping using specific sensorycircuit stimulation and a theoretical graph network analysis in mice with neuropathic allodynia, Sci. Rep., 6 (2016) 37802.

12) Kim, S.H., Chung, J.M., An experimental model for peripheral neuropathy produced by segmental spinal nerve ligation in the rat, Pain, 50 (1992) 355-363.

13) Biswal, B., Yetkin, F.Z., Haughton, V.M., Hyde, J.S., Functional connectivity in the motor cortex of resting human brain using echo-planar MRI, Magn. Reson. Med., 34 (1995) 537-541.

14) Fox, M.D., Greicius, M., Clinical applications of resting state functional connectivity, Front. Syst. Neurosci., 4 (2010) 19.

15) Matsubayashi, K., Nagoshi, N., Komaki, Y., Kojima, K., Shinozaki, M., Tsuji, O., Iwanami, A., Ishihara, R., Takata, N., Matsumoto, M., Mimura, M., Okano, H., Nakamura, M., Assessing cortical plasticity after spinal cord injury by using resting-state functional magnetic resonance imaging in awake adult mice, Sci. Rep., 8 (2018) 14406.

16) Nakamura, M., Tsuji, O., Iwanami, A., Tsuji, T., Ishii, K., Toyama, Y., Chiba, K., Matsumoto, M., Central neuropathic pain after surgical resection in patients with spinal intramedullary tumor, J. Orthop. Sci., 17 (2012) 352-357.

17) Ashburner, J., Friston, K.J., Voxel-based morphometry - the methods, Neuroimage, 11 (2000) 805-821.

18) Horiuchi, Y., Tsuji, O., Komaki, Y., Fujiyoshi, K., Hikishima, K., Konomi, T., et al., Characteristic cerebral structural changes identified using voxel-based morphometry in patients with postoperative myelopathic pain, Spinal Cord, 2019; in press.

19) Fujiyoshi, K., Yamada, M., Nakamura, M., Yamane, J., Katoh, H., Kitamura, K.,Kawai K., Okada, S., Momoshima, S., Toyama, Y., Okano, $\mathrm{H}$., In vivo tracing of neural tracts in the intact and injured spinal cord of marmosets by diffusion tensor tractography, J. Neurosci., 27 (2007) 11991-11998.

20) Konomi, T., Fujiyoshi, K., Hikishima, K., Komaki, Y., Tsuji, O., Okano, H.J., Toyama Y., Okano, H., Nakamura, M., Conditions for quantitative evaluation of injured spinal cord by in vivo diffusion tensor imaging and tractography: preclinical 
longitudinal study in common marmosets, Neuroimage, 63 (2012) 1841-1853.

21) Takano, M., Komaki, Y., Hikishima, K., Konomi, T., Fujiyoshi, K., Tsuji, O., Toyama, Y., Okano, H., Nakamura, M., In vivo tracing of neural tracts in tiptoe walking Yoshimura mice by diffusion tensor tractography, Spine (Phila Pa 1976), 38 (2013) E66-72.

22) Nakamura, M., Fujiyoshi, K., Tsuji, O., Konomi, T., Hosogane, N., Watanabe, K., Tsuji, T., Ishii, K., Momoshima, S., Toyama, Y., Chiba, K., Matsumoto, M., Clinical significance of diffusion tensor tractography as a predictor of functional recovery after laminoplasty in patients with cervical compressive myelopathy, J. Neurosurg. Spine, 17 (2012) 147-152.

23) Fujiyoshi, K., Hikishima, K., Nakahara, J., Tsuji, O., Hata, J., Konomi, T., Nagai, T., Shibata, S., Kaneko, S., Iwanami, A., Momoshima, S., Takahashi, S., Jinzaki, M., Suzuki, N., Toyama, Y., Nakamura, M., Okano, H.., Application of qSpace Diffusion MRI for the Visualization of White Matter, J. Neurosci., 36 (2016) 2796-2808.
24) Inoue, M., Rashid, M.H., Fujita, R., Contos, J.J., Chun, J., Ueda, H., Initiation of neuropathic pain requires lysophosphatidic acid receptor signaling, Nat. Med., 10 (2004) 712-718.

25) Kuwajima, K., Sumitani, M., Kurano, M., Kano, K., Nishikawa, M., Uranbileg, B., Tsuchida, R., Ogata, T., Aoki, J., Yatomi, Y., Yamada, Y., Lysophosphatidic acid is associated with neuropathic pain intensity in humans: An exploratory study, PLoS One, 13 (2018) e0207310.

Address for correspondence: Osahiko Tsuji Department of Orthopaedic Surgery, Keio University School of Medicine 35 Shinanomachi, Shinjuku-ku, Tokyo 160-8582, Japan

※ 本稿は第 41 回日本疼痛学会 (2019 年 7 月, 名古 屋)「公募シンポジウム 2 : 痛みの定量化」の講演 内容をまとめたものである。 